\title{
Reduction the electric field effect generated by high voltage on fiber optic cables using metal shielding
}

\author{
Izz Kadhum Abboud ${ }^{1}$, Shahir F. Nawaf ${ }^{2}$, Mohammed H. Dervish ${ }^{3}$ \\ ${ }^{1}$ Department of Computer Engineering, Mustansiriyah University, Baghdad, Iraq \\ ${ }^{2,3}$ Department of Electrical Engineering, Tikrit University, Iraq
}

\section{Article Info \\ Article history: \\ Received Jun 12, 2019 \\ Revised Aug 10, 2019 \\ Accepted Sep 26, 2019}

\section{Keywords:}

Electric field

Fiber optic cable

Metalshielding

Telecommunications networks

Transmission line

\begin{abstract}
Because of the fiber optic cables have perfect resistant to weather and environmental effects they can be installed on or with transmission line towers for the power supply control and data communication. To avoid the damages of fiber optic cables, it is used shielded fiber optic cables. Due to the using of this shielding, the electric field that produced from transmission line will be effected. In this paper is studied and compared the influence of metal shielding of fiber-optic cable in the strong electric field which produced by a high voltage transmission line for various types of channel configuration. Based on the results obtained, the metal shielding of fiber optic cables will reduce the electric field strength that lead to good efficiency of communication through the optical cable.
\end{abstract}

This is an open access article under the CC BY-SA license.

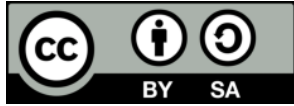

\section{Corresponding Author:}

Izz Kadhum Abboud,

Department of ComputerEngineering,

Mustansiriyah University, Faculty of Engineering,

Baghdad, Iraq.

Email: izz_kadhum@uomustansiriyah.edu.iq

\section{INTRODUCTION}

Due to the geometry of electrical energy transmission line systems, a wide expansion of the field is clear in the high-voltage lines create magnetic and electric fields in their neighborhood. The magnetic fields are caused by the currents in the phase conductors while the electric fields are generated by the high potential of conductors. However [1] Power systems require telecommunication network with a good bandwidth for control the power system s and data communications [2]. Fiber optic cable is one medium that can be used in telecommunications networks along with high voltage transmission lines as well as with extra high voltage because of it is immunological against electromagnetic interference. Varied Effects of weather often caused damaging the ceramic (Shielding) of fiber optic cable contained in transmission line. So to be more resistant against the influence of weather and environment, the shielding that made of materials in optical fiber cable is used [3]. So, we must know the effects of shielding fiber optic cables on electric field produced by transmission line conductors [4].

There is energy in the electric and magnetic fields if there is voltage difference and this energy cannot be ignored easily [5]. The high voltage transmission line configurations and the fiber optic cables generate a shaped area that sets up a group of ca pacitances that able to store and then transfers the energy from the high voltage conductor to the fiber optic cables. In several cases the dispersion of the energy is caused by the electrical field from the high voltage line is taken into account to be the driving force of the currents causing dry-band arcing on the fiber optic cable. Dry-band arcing problems to nearby fiber optic cables cause by high voltage networks due to electric and magnetic fields exist in it [6-7]. The amount 
of dry-band arcing that will be viewed by the adjacent fiber optic cable is limited by the geometry of electrical lines [8]. To prevent damage occur on the cable, electric fields should be controlled. This subject of arc control named shielding and grounding is studied by the physics theory and cannot be solved by using only circuit theory because the geometry of a structure is rarely treated as it appears in the physical world . We know that transmission line will cause the electric field [9]. The presence of metal shielding will affect the strength of this field because it will cause capacitance between metal shielding Conductor wire, and ground [10].

In the alternating current transmission system there are single-phase and three-phase systems. Three-phase system has some advantages compared with the single-phase system because power is distributed over large instantaneous value. Configuration of transmission line can be divided in the single and double transmission line channels [11-12]. Single circuit transmission line has several configurations, namely horizontal configuration, vertical configuration and equilateral triangle configuration. In the horizontal configuration [13]. The three phases are in the same height and with the same inter-conductor separation distance while in the vertical configuration, the three phases arranged vertically with the same separation distance between the conductors as shown in Figure 1. While in the double circuit transmission line, there are several configurations, namely: vertical configuration, triangular configuration, and hexagonalconfiguration [14].

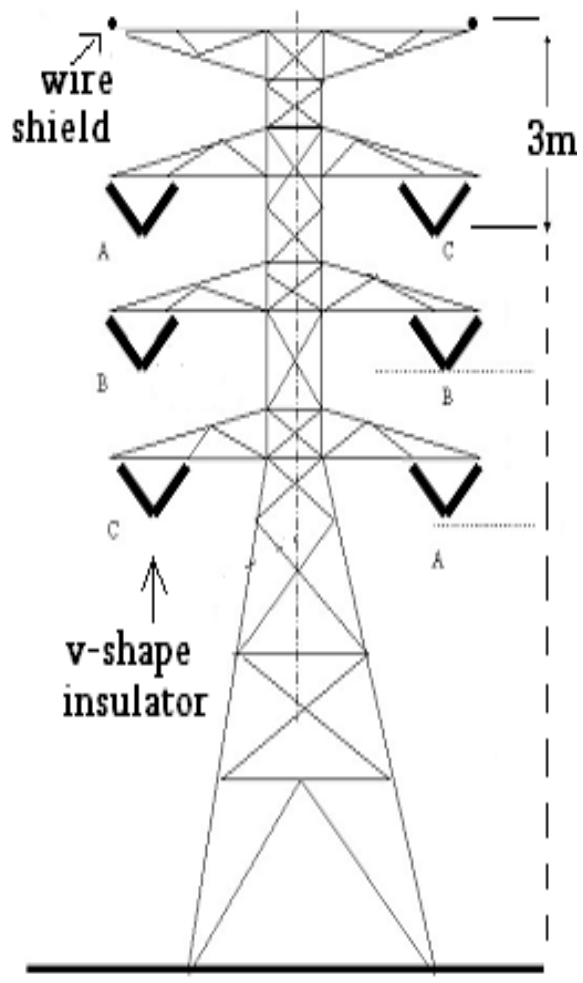

Figure 1. 132KV double circuit configuration transmission line

The optical fiber cable placed at position in a certain distance parallel to the conductive transmission lines. Because the fiber cable optics shielding is made of metal then there is shielding capacitance between shielding fiber optic cable and ground. Because of this capacitance [15] arising electric charge on the metal shielding which affect the strength of the electric field produced by the transmission line conductors. The cable's outer sheathing can be degraded mod as a result of arch current flowing along the cable's sheathing created by the (HEF) high electric voltage from the (HTL) high voltage tra nsmission lines in hat location. Due to the relative geometric location of the (HVC) high voltage conductors and certainly the (FOC) fiber optic cable [16]. The fiber optic cable will be coupled by based capacitors between the (HTL) and the metal shielded roundabout. The voltage difference between the (HVL) and the (FOC) implies a charge distribution on the groups of (FOC) [17]. 
Perhaps levels of $220 \mathrm{KV}$ or higher led to cable sheathing failures in less than a year or two years after installation and application of course [18]. Examination of the damage in these early failures presented, what may be electrical damage near the supports. Some theories really ensued tried to explain and maybe solve the events leading to the cables dropping out of service [19]. Dry-band arcing is now almost acknowledged to be the major cause of damage strengthen by the cables tension in a high voltage climate. Research at Universityof Arizona State in joint efforts with (WPA) Western Power Administration, and (EPRI) Electric Power Research Institute has developed an experimental setup to imitate the dry-band arcing electrical damageobserved on the (FOC) sheathing (BPA) Bonneville Power Administration alsocontributed to the modern study [20].

\section{RESEARCH METHOD}

We will calculate and measure the electric field strength caused by the transmission line network with presence of metal shielded fiber optical cable and without metal shielded fiber optical cable [21]. Then we will make a comparison between two results obtained from these calculations. So [22] electric and magnetic fields in the substation has been performed by measurements of electric field $(\mathrm{KV} / \mathrm{m})$ with and without fiber optic cable for or the double circuit configuration in accordance to the range and measurements of electric field $(\mathrm{kv} / \mathrm{m})$ with and without fiber optic cable for double circuit configuration in accordance to the elevationand comparison the results [23].

\subsection{Mathematical calculations}

Calculation of electric field strength in soil surface at a certain distance from transmission line can be done using the following equation [24, 25]:

$$
\begin{aligned}
& E=\frac{q_{i}}{2 \pi \cdot r \cdot \varepsilon 0} \\
& E=\frac{q_{i}}{2 \pi \varepsilon_{0}\left(h^{2}+L^{2}\right)^{1 / 2}}
\end{aligned}
$$

Electric field of vertical components above ground is:

$$
E \cos \theta=\frac{q_{i}}{2 \pi \varepsilon_{0}\left(h^{2}+L^{2}\right)^{1 / 2}} x \frac{h}{\left(h^{2}+L^{2}\right)^{1 / 2}}=\frac{q_{i}}{2 \pi \varepsilon_{0}\left(h^{2}+L^{2}\right)}
$$

Where; $h=$ height of the conductor

$\mathrm{L}=$ distance of the conductors from midpoint $(0$ axes) or center of tower

\section{RESULTS AND DISCUSSION}

Calculation results for the double circuit configuration can be seen in Table 1 and Table 2 . In the Figure 2 it can be seen that the electric field with and without fiber optical cable which sharply decreases to almost close to zero, then slightly rise and slowly back down until a strong electric field becomes zero. This caused by the configuration channel. This is a vertically configuration in which vertically Conductor arranged from top to bottom with a particular distance. In this configuration there's a largest value of electric field strength at the midpoint of transmission line. In Figure 3 for transmission line without optical fiber cable the greatest strength field located at the midpoint of the transmission line is equal to $(0.65683$ $\mathrm{kV} / \mathrm{m})$ and then sharply fell until it reaches $(0.007793 \mathrm{kV} / \mathrm{m})$ at a distance of $14 \mathrm{~m}$ from the middle point of the transmission line and then rise and becomes $(0.02968 \mathrm{kV} / \mathrm{m})$ at a distance of $(22) \mathrm{m}$ and thereafter gradually decreased until electric field strength became zero. For the transmission line with a fiber optical cable is located the largest field strength at the midpoint of the transmission line is amounted to 0.451042 $\mathrm{kV} / \mathrm{m}$ and then sharply decreased until it reaches $(0.011539) \mathrm{kV} / \mathrm{m}$ at a distance of $14 \mathrm{~m}$ from the midpoint of transmission line and then rise to $(0.036033 \mathrm{kV} / \mathrm{m})$ at a distance of $(22) \mathrm{m}$ and after it gradually fell to a zero. At a distance of ( 0 up to 12 ) $\mathrm{m}$ electric field generated by transmission line without fiber optical cable greater compared with the transmission line with fiber optical cable. While for the distance (14 up to 50) meter the case is inverse. This is caused by capacitance and the configuration of the transmission line. In the figure above the electric field at the midpoint of the transmission line increases with increasing the height of the surface. 
Table 1. Measurements of electric field $(\mathrm{kV} / \mathrm{m})$ with and without fiber optic cable

\begin{tabular}{cccccc}
\hline $\begin{array}{c}\text { range } \\
(\mathrm{m})\end{array}$ & $\begin{array}{c}\text { electric field } \\
(\mathrm{kV} / \mathrm{m}) \text { with fiber } \\
\text { optic cable }\end{array}$ & $\begin{array}{c}\text { electric field } \\
(\mathrm{kV} / \mathrm{m}) \text { without fiber } \\
\text { optic cable }\end{array}$ & $\begin{array}{c}\text { range } \\
(\mathrm{m})\end{array}$ & $\begin{array}{c}\text { electric field }(\mathrm{kV} / \mathrm{m}) \\
\text { with fiber optic } \\
\text { cable }\end{array}$ & $\begin{array}{c}\text { electric field }(\mathrm{kV} / \mathrm{m}) \\
\text { without fiber optic } \\
\text { cable }\end{array}$ \\
\hline 2 & 2.345 & 3.412 & 28 & 2.786 & 2.742 \\
4 & 2.965 & 3.551 & 32 & 2.112 & 2.211 \\
8 & 4.567 & 3.952 & 36 & 1.565 & 1.542 \\
12 & 5.657 & 5.341 & 40 & 1.221 & 0.995 \\
16 & 5.453 & 5.301 & 44 & 0.976 & 0.802 \\
18 & 5.231 & 5.101 & 46 & 0.811 & 0.765 \\
20 & 4.789 & 4.658 & 48 & 0.776 & 0.543 \\
24 & 3.721 & 3.685 & 50 & 0.564 & \\
\hline
\end{tabular}

Table 2. Measurements of electric field $(\mathrm{kV} / \mathrm{m})$ with and without fiber optic cable for double circuit configuration in accordance to the elevation

\begin{tabular}{cccccc}
\hline $\begin{array}{c}\text { Elevation } \\
(\mathrm{m})\end{array}$ & $\begin{array}{c}\text { Electric Field } \\
(\mathrm{kV} / \mathrm{m}) \text { with } \\
\text { fiber optic cable }\end{array}$ & $\begin{array}{c}\text { Electric Field(kV/m) } \\
\text { without fiber optic } \\
\text { cable }\end{array}$ & $\begin{array}{c}\text { Elevation } \\
(\mathrm{m})\end{array}$ & $\begin{array}{c}\text { Electric Field } \\
(\mathrm{kV} / \mathrm{m}) \text { with fiber } \\
\text { optic cable }\end{array}$ & $\begin{array}{c}\text { Electric Field } \\
(\mathrm{kV} / \mathrm{m}) \text { without fiber } \\
\text { optic cable }\end{array}$ \\
\hline 0.2 & 2.431 & 3.631 & 1.8 & 3.438 & 4.870 \\
0.4 & 2.541 & 3.786 & 2 & 3.541 & 4.988 \\
0.8 & 2.654 & 3.989 & 2.2 & 3.653 & 5.198 \\
1 & 2.8 & 4.212 & 2.4 & 3.762 & 5.445 \\
1.2 & 2.987 & 4.321 & 2.6 & 3.875 & 5.536 \\
1.4 & 3.128 & 4.504 & 2.8 & 3.973 & 5.675 \\
1.6 & 3.246 & 4.657 & 3 & 4.127 & \\
\hline
\end{tabular}

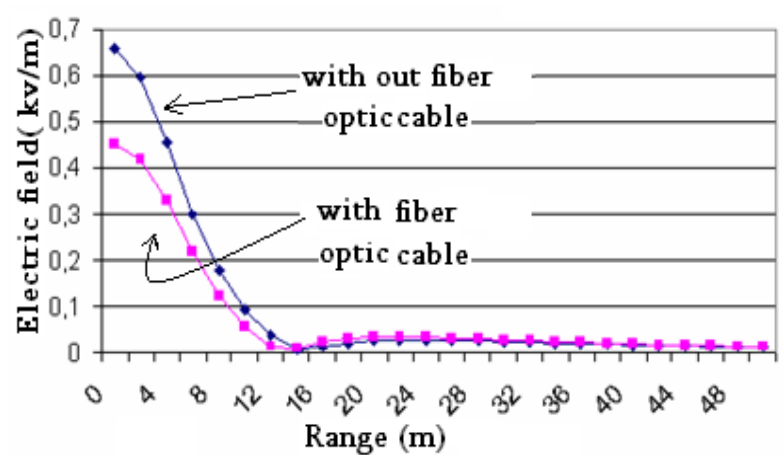

Figure 2. Electric field for double vertical configuration

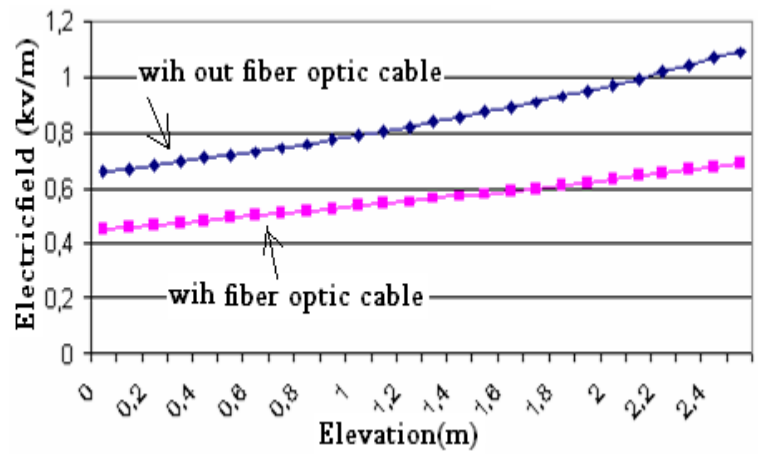

Figure 3. Electric field of double vertical configuration according to land surface

\section{CONCLUSION}

In the transmission line double vertical configuration Circuit with fiber optics cable, the generated electric field at a distance of 0 to $10 \mathrm{~m}$ is less than the transmission line without fiber optic wires, while for distances greater than $10 \mathrm{~m}$ state in reverse. In this configuration, the largest electric field strength is at a distance of $14 \mathrm{~m}$ from the midpoint of the transmission line. In transmission line double vertical configuration circuit with fiber optic cable, the generated electric field at a distance of (4) $\mathrm{m}$ is less than the transmission line circuit without optical fiber wires, while for distances greater than (12) $\mathrm{m}$ state in reverse. In this configuration, the largest electric field strength is at the midpoint transmission line or at a distance of $(0) \mathrm{m}$. In this configuration, electric field strength caused by transmission line with fiber optic cables in generally less than the transmission line without optical fiber cable. The results obtained can be used for determining the free distance of transmission line installation, if shielding optical fiber cable done by using metalshielding.

\section{ACKNOWLEDGEMENTS}

The authors thank Mustansiriya University for its full support of this work. It is on e of the Iraqi public and famous universities named after the Mustansiriya school, which was founded in the time of the Abbasids in Baghdad in 1233 by the Caliph Al-Mustansir Billah. It was an important scientific 
and cultural center. Located now in the capital Baghdad. Includes 13 faculties. Founded in 1963. www.uomustansiriyah.edu.iq

\section{REFERENCES}

[1] L. A. Dissado, M. J. Parry, S. V. Wolfe, A. T. Summers, C. N. Carter, "A new sheath Evaluation technique for self-supporting optical fibre cables on overhead power Lines," Proceedings of 39th International Wire and Cable Symposium, Shrewsbury, NJ, USA, pp. 743-751, 1990.

[2] M. W. Touminen, "3 Phase circuit model for ADSS optical fiber contamination currents," Engineering Report TNL3-99-1, Bonneville Power Administration, US Department of Energy, May 1999.

[3] J. C. G. Wheeler, M. L. Lissenburg, J. D. S. Hinchliffe and M. E. Slevin, "The development and testing of a track resistant sheathing material for aerial optical fibre cables," 1988 Fifth International Conference on Dielectric Materials, Measurements and Applications, Canterbury, UK, 1988, pp. 73-76.

[4] S. M. Rowland, K. Craddock, et. al., "The development of a metal-free, self supporting optical cables for use on long span high-voltage overhead power lines," Proceedings of the 36th International Wire and Cable Symposium, Arlington, pp. 449-456, 1987.

[5] The Furukawa Electric Co., Ltd., "Optical fibers and cables," http://www.furukawa.co.jp/english/product/jotsu1_e.htm, May 2000.

[6] Resource Site prepared by CAO Long Qing, "Fiber optic cable resource site," http://csadfa.cs.adfa.edu.au/ mariamf/int-tele/assign1/cao/cao.htm, May 2000.

[7] C. N. Carter, "Dry band electrical activity on optical cables separately strung on Overhead power lines," Proceedings of the 37th IWCS, Reno, pp. 117-121, November 1988.

[8] A. G. W. M. Berkers and J. M. Wetzer, "Electrical stresses on a selfsupporting metal-free cable in high voltage networks," 1988 Fifth International Conference on Dielectric Materials, Measurements and Applications, Canterbury, UK, 1988, pp. 69-72.

[9] Telecommunication Industry Association, "Communications in the 21st Century," http://www.atalink.co.uk/tia/, June 2000.

[10] American National Standards Institute, "Standards and conformity assessment information," http://www.ansi.org/, April 2000.

[11] S. M. Rowland and C. N. Carter, "The evaluation of sheathing materials for an all dielectric self-supporting communication cable, for use on long span, overhead power lines," 1988 Fifth International Conference on Dielectric Materials, Measurements and Applications, Canterbury, UK, 1988, pp. 77-80.

[12] International Organization for Standardization, "ISO online," http://www.iso.ch/, May 2000.

[13] International Electrotechnical Commission, "Standards and assessment of electrotechnology," http://www.iec.ch/, April 2000.

[14] Centre for Marine \& Coastal Studies. "A baseline assessment of electromagnetic fields generated by offshore windfarm cables." Report to Collaborative Offshore Wind Research into the Environment (COWRIE) group, Crown Estates, 2003.

[15] John J. Karakash, "Transmission Lines and Filter Networks (First ed.)," New York, NY: Macmillan, pp. 44.1950.

[16] Corning Cables, "AirLite ADSS optical fibre cable," http://www.corningcables.com.au/airlite.htm, May 2000.

[17] R. G. Olsen, "An improved model for the electromagnetic compatibility of all-dielectric self-supporting fiber-optic cable and high-voltage power lines," in IEEE Transactions on Electromagnetic Compatibility, vol. 41, no. 3, pp. 180-192, Aug. 1999.

[18] C. N. Carter, "Arc control devices for use on all-dielectric self-supporting, optical cables," in IEE Proceedings A-Science, Measurement and Technology, vol. 140, no. 5, pp. 357-361, Sept. 1993.

[19] LabVIEW, National Instruments Corporation, 11500 N. MopacExpwy, Austin, TX, 78759-3504.

[20] C. N. Carter and M. A. Waldron, "Mathematical model of dry-band arcing on self-supporting, all-dielectric, optical cables strung on overhead power lines," in IEE Proceedings C-Generation, Transmission and Distribution, vol. 139, no. 3, pp. 185-196, May 1992.

[21] S. M. Rowland and I. V. Nichols, "Effects of dry-band arc current on ageing of self-supporting dielectric cables in high fields," in IEE Proceedings-Science, Measurement and Technology, vol. 143, no. 1, pp. 10-14, Jan. 1996.

[22] R. Inger, M. J. Attrill, et al. "Marine renewable energy: potential benefits to biodiversity? An urgent call for research," Journal of Applied Ecology, vol. 46, pp. 1145-1153, 2009.

[23] G. W. Boehlert and A. B. Gill, "Environmental and ecological effects of ocean renewable energy development-a current synthesis," Oceanography, vol. 23, pp. 68-81, 2010.

[24] G. Carlton, A. Bartlett, C. Carter, T. Parkin, "UK power utilities' experience with optical telecommunications cabling systems," Power Eng. J., vol. 9, pp. 7-14, Feb. 1995

[25] C. N. Carter, M. A. Waldron, "Mathematical model of dry-band arcing on self-supporting all-dielectric optical cables strung on overhead power lines," Proc. Inst. Elec. Eng., vol. 139, no. 3, pp. 185-196, May 1992. 


\section{BIOGRAPHIES OF AUTHORS}
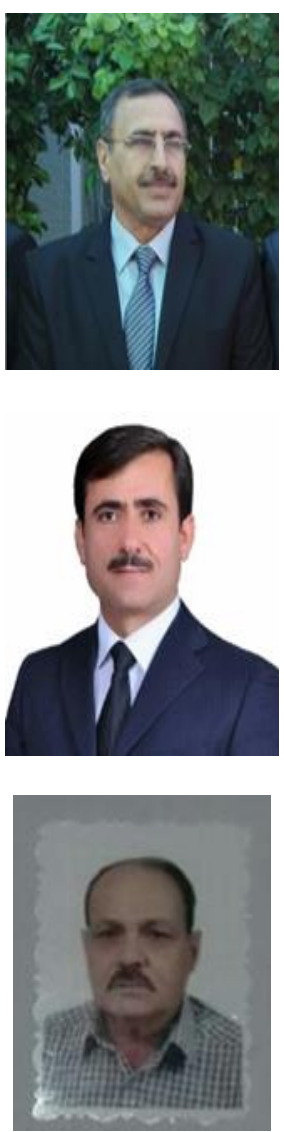

Izzkadhumabboud was born in Erbil/Iraq 1962. He received B.Sc. degree in electrical \& Electronic engineering from Sarajevo/Bosnia 1984 and M.Sc. degree in Electronic \& communication engineering from University of Belgrade/Serbia 1986, in 1994. He had worked at airplanes repairing factory in electronic department/Baghdad/Iraq, in 1996 he had worked in Air force training institute communication department/Baghdad/Iraq, in 2000 he worked as a lecturer in Institute of Technology/Baghdad/Iraq, in 2005 he worked as a lecturer in Mustansiriyah University Faculty of Engineering Computer department/Baghdad/Iraq and currently he still three. His research interests electronics fields and communications fields, he has many research papers in different journals and conferences.

E-mail: izz_kadhum@uomustansiriyah.edu.iq

Shahir Fleyeh Nawaf was born in Mosul/Iraq 1961 .He received B.Sc. Degree in Electrical \& Electronic engineering from Sarajevo University 1985. And M.Sc. Degree in Electronic \& Communication engineering from University of Belgrade/Serbia 1987. In 1989. He had worked at Air force communication department/Baghdad/Iraq. in 1992 he Worked at communication repairing factory in electronic department /Baghdad/Iraq.In 1999 he worked at Al-Fatah company for manufacturing the communications equipment. in 2006 he had worked as a lecturer in Tikrit University/Faculty of Engineering/Electrical Department/Iraq \& currently he still. He has many research papers interests Electronics \& Communications field.

E-mail: shahir735@gmail.com

Mohammed Hassan Dervish was born in Tikrit/Iraq 1962 .He received B.Sc. Degree in Electrical \& Electronic engineering from Sarajevo University 1984. And M.Sc. Degree in Electronic \& Communication engineering from University of Belgrade/Serbia 1986. In 1993. He had worked at Air force communication department/Baghdad/Iraq. In 2006 he had worked as a lecturer in Tikrit University/Faculty of Engineering/Electrical Department/Iraq \& currently he still there. $\mathrm{He}$ has many research papers interests Electronics \& Communications field. E-mail: mohammed_eng62@tu.edu.iq 